\title{
Can State Taxes Redistribute Income?
}

\section{Citation}

Feldstein, Martin and Marian Vaillant. 1994. Can state taxes redistribute income? Journal of Public Economics 68(3): 369-396.

\section{Published Version}

http://dx.doi.org/10.1016/S0047-2727(98)00015-2

\section{Permanent link}

http://nrs.harvard.edu/urn-3:HUL.InstRepos:2799054

\section{Terms of Use}

This article was downloaded from Harvard University's DASH repository, and is made available under the terms and conditions applicable to Other Posted Material, as set forth at http:// nrs.harvard.edu/urn-3:HUL.InstRepos:dash.current.terms-of-use\#LAA

\section{Share Your Story}

The Harvard community has made this article openly available.

Please share how this access benefits you. Submit a story.

\section{Accessibility}


NBER WORKING PAPER SERIES

\author{
CAN STATE TAXES \\ REDISTRIBUTE INCOME?
}

\author{
Martin Feldstein \\ Marian Vaillant
}

Working Paper No. 4785

\title{
NATIONAL BUREAU OF ECONOMIC RESEARCH 1050 Massachusetts Avenue \\ Cambridge, MA 02138 \\ June 1994
}

Martin Feldstein is Professor of Economics at Harvard University and President of the National Bureau of Economic Research. Marian Vaillant is a graduate student at Harvard University and a research assistant at the NBER. We are grateful to members of the NBER Public Economics Program and the Harvard-MIT Public Finance Seminar for discussions and comments on this work and to Daniel Feenberg for assistance with the TAXSIM calculations reported in section 5. This paper is part of NBER's research program in Public Economics. Any opinions expressed are those of the authors and not those of the National Bureau of Economic Research. 
NBER Working Paper \#4785

June 1994

\title{
CAN STATE TAXES \\ REDISTRIBUTE INCOME?
}

\begin{abstract}
The evidence presented in this paper supports the basic theoretical presumption that state and local governments cannot redistribute income. Since individuals can avoid unfavorable taxes by migrating to jurisdictions that offer more favorable tax conditions, a relatively unfavorable tax will cause gross wages to adjust until the resulting net wage is equal to that available elsewhere. The current empirical findings go beyond confirming this long-run tendency and show that gross wages adjust rapidly to the changing tax environment. Thus, states cannot redistribute income for a period of even a few years.

The adjustment of gross wages to tax rates implies that a more progressive tax system raises the cost to firms of hiring more highly skilled employees and reduces the cost of lower skilled labor. A more progressive tax thus induces furms to hire fewer high skilled employees and to hire more low skilled employees.

Since state taxes cannot alter net wages, there can be no trade-off at the state level between distribution goals and economic efficiency. Shifts in state tax progressivity, by altering the structure of employment in the state and distorting the mix of labor inputs used by firms in the state, create deadweight efficiency losses without achieving any net redistribution of income.
\end{abstract}

\author{
Martin Feldstein \\ National Bureau of Economic Research \\ 1050 Massachusetts Avenue \\ Cambridge, MA 02138 \\ and NBER
}

Marian Vaillant

National Bureau of Economic Research

1050 Massachusetts Avenue

Cambridge, MA 02138 


\section{Can State Taxes Redistribute Income?}

Martin Feldstein and Marian Vaillant*

State governments cannot redistribute income if individuals can migrate among political jurisdictions. Although state tax structures may appear to be redistributive, real pretax wages must adjust in the long run to make each individual's potential after-tax real income the same in all jurisdictions. If the after-tax real income available to an individual were higher in one state than in another, individuals would locate in states where real net incomes were more favorable. In response to differences in the progressivity of tax rates, migration would raise pretax real incomes of high income individuals in states where such individuals were taxed more heavily and lower pretax incomes of lower income individuals in such states. In equilibrium, the real after tax income would be independent of the state tax structure. ${ }^{1}$

Although a relatively more progressive state tax structure cannot achieve a long-run redistribution of income, it does distort economic choices and thereby reduces total real incomes. This distortion of economic choices involves more than the traditional impact on the intensity of work effort and on portfolio allocation that cause progressive taxes in a closed economy to

1 This theory of long-run spatial fiscal equilibrium is implied by the original Tiebout (1956) analysis and has been recognized by Oates (1972), Stiglitz (1988), etc.. Gordon (1986) makes a similar point with respect to capital income in open economies.

* Martin Feldstein is Professor of Economics at Harvard University and President of the National Bureau of Economic Research (NBER). Marian Vaillant is a graduate student at Harvard University and a research assistant at the NBER. We are grateful to members of the NBER Public Economics Program and the Harvard-MIT Public Finance Seminar for discussions and comments on this work and to Daniel Feenberg for assistance with the TAXSIM calculations reported in section 5 .

statctax.60794 
have a greater dead weight loss than a proportional tax that raises an equal amount of revenue (Musgrave, 1973; Atkinson and Stiglitz, 1980). A change in the progressivity of the state tax also induces a geographic reallocation of resources and a change in the production technology within the state. As pretax wages of highly skilled individuals rise and pretax wages of lower skilled individuals fall, firms are induced to reduce the number of higher paying jobs and to increase the number of lower paying jobs.

In short, there is no long-run tradeoff between income redistribution and economic efficiency when individuals are free to migrate. A more redistributive state tax structure reduces economic efficiency without changing the distribution of net income. And yet some states and even some cities do enact graduated income taxes and differential sales taxes. In 1992, seven states had no income tax at all while five states had graduated income taxes with marginal tax rates that reached 10 percent or more. More generally, as part of this study we have calculated the overall state tax rate (including the personal income tax, state sales tax and local property tax) in each state in 1983 for taxpayers with incomes of $\$ 25,000$ and $\$ 100,000^{2}$. The average tax rate at the $\$ 25,000$ income level varied from less than two percent to more than 9 percent. At an income of $\$ 100,000$, the average tax rate varied from a low of 1.2 percent to a high of 9.6 percent. The degree of progressivity, as measured by the difference between the average tax rates at $\$ 100,000$ and at $\$ 25,000$, varied from a high of 3.4 percent in Vermont to a low of

\footnotetext{
'We calculate these tax rates for 1983 because that permits us to use the estimated sales tax rates by income and family type previously estimated by Feenberg and Rosen (1986). Our estimates are for a married couple with two dependents. The method of calculating the property laxes is described in section 4 of the current paper. The NBER TAXSIM model is used to calculate the state income tax which is then combined with sales tax rates and the property taxes to estimate the overall tax burden at each income level. The actual rates for 1983 (and corresponding rates for 1989 excluding sales taxes) appear in the Appendix.
} 
minus 1.7 percent in Wyoming. In 20 of the states the average tax rate was higher at $\$ 25,000$ than at $\$ 100,000$.

Since a state tax structure that is more graduated than average does not change the longrun distribution of real net income in the state but does reduce economic efficiency, why do states enact such tax structures? There are five possible explanations.

First, the transition to the long-run equilibrium in which changes in pretax real incomes offset changes in tax rates may take such a long time to occur that a substantial amount of fiscal redistribution is possible. Voting majorities may enact graduated tax structures to redistribute income during this transition period. Even though there is no long-run opportunity for a tradeoff between income redistribution and economic efficiency, there could in principle be a present value tradeoff between the politically desired income redistribution and the loss of economic efficiency. We shall refer to this explanation as the delayed adjustment hypothesis. An important purpose of the current study is to assess not only whether the independence of net wages from the state tax structure occurs in the long run but also whether the adjustment to changes in state tax structures happens very slowly or so quickly that the delayed adjustment hypothesis cannot justify attempts at redistributive tax policy.

The second possible explanation is that a more graduated tax structure may reflect the structure of benefits provided by the state, leaving no net fiscal redistribution. We refer to this as the benefit taxation hypothesis. Although much of state spending is on services like Medicaid that benefit lower income households, some state spending like higher education programs and state education grants to local governments may favor higher income households. What matters for this explanation is that the extent to which any state's tax structure is more graduated than 
the tax structures in other states is matched by a distribution of benefits that differs from that available elsewhere by a compensating amount. If the tax structure and the benefit structure are balanced in this way, the individual has no reason to migrate. To the extent that this benefit taxation hypothesis is true, the degree of tax progressivity in the state will not alter real pretax wages.

The third possible explanation, which we denote the tax capitalization hypothesis, is that the change in real pretax wages is achieved in part by changes in property values rather than (or in addition to) changes in money wages. In the extreme, if money wages were unchanged and the state tax structure was reflected wholly in property values, there would be no deadweight loss and a once and for all redistribution based on the initial distribution of property ownership. More generally, even if the capitalization of taxes in property values were only partially true, an increase in progressivity might lower the value of property in the high income areas of the state and raise the value of property in low income ares of the state. A state that wanted to reduce the wealth of current high income residents and to increase the wealth of the owners of lower income housing (many of whom would be the higher income owners of the apartments of the lower income renters) could achieve this by an increase in the progressivity of the state income and sales tax.

A fourth possible explanation is federal tax deductibility. A more graduated tax structure causes the federal government to increase its indirect fiscal subsidy to the state because higher income residents are more likely to deduct taxes in calculating federal taxable income and because these deductions will generally be subject to higher federal marginal tax rates. The federal deductibility reduces but does not eliminate the local deadweight loss and does provide 
some compensation for accepting that loss. In a separate paper we have examined the hypothesis that federal tax deductibility explains state tax progressivity and find no statistical support. State taxes are not more progressive where deductibility is more common or where the federal marginal tax rate of itemizers is greater (Feldstein and Vaillant, 1994).

The final possible explanation that we consider is fiscal illusion. Even if the adjustment delays are very small, so that essentially no redistribution of real income is achieved, politicians may promote a graduated tax structure because they expect it to be popular with a majority of voters who do not understand that pretax real wages would adjust, leaving no change in real disposable incomes. Alternatively, the politicians themselves may not understand that no real income redistribution is achieved by changing the rate structure.

These alternative explanations have very different implications for the relation between the state tax structure and the wages of individuals in that state. Each of the first three explanations implies that the money wages of employees in the state will not have adjusted enough to offset differences in state tax rates. Individuals with the same human capital would earn different net-of-tax money wages because the equilibrium adjustment has not yet occurred (the delayed adjustment hypothesis) or because those differences in net money wages are compensated by differences in benefits (the benefit taxation hypothesis) or by differences in property values and associated rental costs (the capitalization hypothesis).

The econometric estimates that we present in this paper imply the opposite: pretax money wages have adjusted so that state tax rates (net of federal deductibility) do not affect netof-tax money wages. The net-of-tax money wage that an individual earns reflects his or her human capital (education, experience, etc.) and not the tax rate that the individual faces in the 
particular state. This indicates that the adjustment of wages to tax rates is fast enough so that the delayed adjustment hypothesis cannot justify the desire to have a more progressive tax structure. Similarly, it shows that there are not differences in property values or state benefit distributions (or a combination of the two) that need to be compensated by differences in net-oftax money wages. The data therefore suggest that attempts at using state taxes to redistribute income are based on fiscal illusion, i.e., that the true effect of changing state tax progressivity is not understood by politicians, voters, or both. Only the federal government or, equivalently, states acting in concert can achieve a redistribution of after-tax income. ${ }^{3}$

Section 1 of this paper discusses our approach to analyzing the effect of state tax progressivity and some of the caveats that should be borne in mind when interpreting the econometric evidence. The second section presents a formal model of the relation between progressivity, property values and wages. Section 3 discusses our data and the construction of key variables. The econometric issues of endogeneity and state-specific effects are discussed briefly in the fourth section. The statistical estimates are presented in section 5 . The final section comments on the implications of the findings for the use of graduated taxes at the state and local level and, more generally, in countries when there is substantial scope for inward and outward migration.

\footnotetext{
'If a large enough number of states raised tax progressivity, the individuals in those states would have a more limited opportunity to migrate elsewhere and the migration would cause pretax wages in the remaining stales to decline by more than a marginal amount. No single "small" siate can achieve a redistribution of after-tax income.
} 


\section{State Tax Progressivity and Real Net Wages}

In the very long run, an individual's utility level must be independent of the state where he or she lives. If a higher utility level were available elsewhere, the individual would move to the alternative jurisdiction. In a simplified model, this is equivalent to saying that the net-oftax wage does not reflect the local tax structure. The net wage depends only on the individual's human capital attributes (education, age, experience, etc) and on the characteristics that make the state a more or less desirable place to live (e.g., climate, recreational opportunities, public services, general cost of living, etc.). Thus,

$$
w_{\mathrm{Ns}}=f\{\text { human capital attributes of individual } i \text {, characteristics of state } s\}+e_{i}
$$

where $w_{\mathrm{Na}}$ is the net wage of individual $i$ who works in state $s$. This net wage is the difference between the gross pretax wage and the combined tax paid to the federal, state and local governments.

To test this simplified version of the constant net wage hypothesis, we modify the standard loglinear wage equation relating gross wages to human capital attributes of individual $\mathrm{i}\left(\underline{x}_{i}\right)$ and characteristics of state $s\left(\underline{z}_{3}\right)$ by adding an appropriate tax variable:

$$
\ln \mathrm{w}_{\mathrm{Gis}}=\alpha+\beta \ln \left[1-\mathrm{NATR}_{\mathrm{is}}\right]+\gamma^{\prime} \mathrm{x}_{\mathrm{i}}+\delta^{\prime} \mathrm{z}_{\mathrm{i}}+\epsilon_{\mathrm{i}}
$$

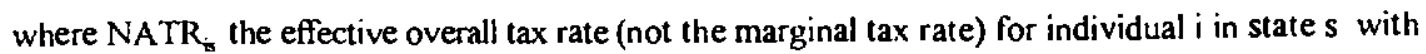
proper attention to the fact that state and local taxes are deductible in calculating income subject to 
the federal income tax. If the coefficient of the net-of- tax variable is equal to minus one $(\beta=-$ 1), the net wage is unaffected by the tax, i.e., the specification is equivalent to a regression of the logarithm of the net-of-tax wage $\left[w_{\mathrm{Gid}}\left(1-\mathrm{NATR}_{\mathrm{is}}\right)\right]$ on personal and state attributes. Conversely, if $\beta=0$ the gross wage is unaffected by the tax so that the net wage falls by the full amount of the $\operatorname{tax}$.

Four qualifications and cautions must be noted about this approach to testing the hypothesis that state and local tax progressivity does not affect real net incomes.

First, as a practical matter, it is not possible to specify all of the attributes of the state that might affect individuals' desires to live in that state. We therefore use dummy variables to introduce a separate constant term for each state, replacing the constant $\alpha$ of equation 2 with a separate $\alpha_{2}$ for each state. In this fixed effects model, the variables that are constant within each state $(\underline{\underline{z}})$ are automatically eliminated from the specification. This specification also implies that the estimated effect of the tax variable $(\beta)$ refers to effects of the variation of $1-$ NATR $_{i}$ around the mean value of that variable for the state, i.e., the coefficient of the tax variable measures the effect of tax progressivity rather than the effect of the overall level of the tax variable.

There is one caveat that should be noted about this approach to dealing with state characteristics. The use of state constant terms to eliminate the state characteristics, like the linear specification of equation 2 , assumes that within the state the level of benefits provided to an individual is not correlated with that individual's level of taxes. If, contrary to this assumption, the individuals who pay higher taxes in state s also receive relatively higher benefits from state s (e.g., a state university system that is attended primarily by the children of high income residents), the tax variable overstates the true progressivity of the state fiscal system as a whole and the estimate of $\beta$ 
will be biased toward zero, i.e., toward accepting the view that fiscal variables do not alter gross wages and therefore that net wages are not independent of the tax structure. Conversely, the opposite bias would be true if states that choose progressive tax systems in order to favor lower income households also use the distribution of spending to achieve that goal by giving smaller than average benefits to higher income individuals within the state.

The second caveat in interpreting regressions based on equation 2 is that the specification makes no adjustment for possible differences in the local price index faced by each individual, particularly for the rental prices of property. Although a change in the overall level of property rents in state $s$ would be captured by the state constant term, interstate differences in tax progressivity could in principle cause interstate differences in the pattern of property prices. If high income individuals face relatively lower rents in states with more progressive tax structures, evidence that greater tax progressivity lowers the net wages of high income individuals would not imply that their real net incomes were affected by tax progressivity. The formal model presented in the next section clarifies this role of tax capitalization in property values and rents.

Third, our analysis interprets the coefficient of the net of tax variable as a measure of the extent to which potential geographic mobility permits individuals to avoid the extra burden of the state's tax progressivity. But even in a closed economy with no possibility of migration or trade, individuals will bear less than the full statutory burden of the tax if they reduce their labor supply by working fewer hours, working less intensively, acquiring less education and training, etc. Implicit in our interpretation therefore is the assumption that the response on the intensity margin is less than the geographic response. Although we believe that there are substantial labor supply 
responses to higher marginal tax rates, the scope for the geographic response is greater and tends to an infinitely elastic response as the time to adjustment increases. Even if the potential geographic mobility is enough to keep real net wages unchanged, a more progressive state tax structure could cause some additional adverse labor supply response. To the extent that we attribute all observed tax shifting to potential geographic mobility, we may overstate its importance.

Finally, our analysis focuses on money income alone and ignores other attributes of jobs. The specification of equation 2 is incomplete in not recognizing that individuals with given human capital car: choose more fringe benefits and better working conditions instead of higher money wages. To the extent that they are induced to do so by higher tax rates, the data will show that gross wages are lower where tax rates are higher and our analysis will understate the extent to which potential geographic mobility causes tax shifting, i.e., will lead to an underestimate of the value of $\beta$.

\section{A Simple Model of State Tax Progressivity}

This section presents a simple model of the long-run effect of state tax progressivity on the local wage distribution. The model explicitly introduces land values and therefore the possibility that state income taxes are capitalized in property values." The analysis shows that

${ }^{4}$ See Eissa (1994) and Feldstein (1993) for recent evidence and for references to earlier studies. Higher marginal tax rates may also induce outmigration because they make the terms on which individuals can trade their labor for goods less favorable.

${ }^{9}$ We are not aware of any similar model that deals with the effects of state tax progressivity on wage differentials. Gyuorko and Tracy (1989) and Wallace (1993) discuss how taxes and other local attributes can affect local wages but their analyses deal with average tax levels and not with the issue of progressivity. Wallace's analysis also does not include property values and therefore explicitly ignores the possibility of capitalization. 
the degree of substitutability of land use between high income individuals and low income individuals can have an important effect on the way that money wages respond to changes in state tax progressivity even though potential mobility assures that changes in state tax progressivity do not alter real net incomes.

Consider an economy with two groups of employees, the high skilled (denoted by subscript $H$ ) and the low skilled (denoted by subscript $L$ ). Their gross wages in the state are $w_{H}$ and $w_{\mathrm{L}}$ and these are subject to proportional state taxes at rates $t_{\mathrm{H}}$ and $t_{\mathrm{L}}$. The local prices faced by high and low skill workers ( $p_{H}$ and $p_{L}$ ) may differ because of differences in the prices of housing services faced by the high skilled and low skilled workers. ${ }^{6}$ With this notation, the equilibrium condition that the real net wage in the state for each type of employee is the same as that available to such employees elsewhere $\left(\omega_{H}\right.$ and $\left.\omega_{\mathcal{L}}\right)$ can be written:

(3)

$$
\left(1-t_{H}\right) w_{H} / p_{H}=\omega_{H}
$$

$$
\left(1-t_{L}\right) w_{L} / p_{L}=\omega_{L}
$$

'The possibility of different housing prices for high and low skilled individuals (i.e., high and low income individuals) depends on the length of the adjustment period and the degree of homogeneity of the property in the state. At one extreme, if the state can be considered a featureless plane, there can be no differences in housing prices in the very longest time horizon. If the housing stock changes more slowly than the labor force and, the two types of housing cannot be converted from one use to the other, different prices per unit of housing can prevail in a time period that is long enough for labor market equilibrium to be established. Indeed, if the property in the state is not homogeneous (e.g., some property has nicer views, more convenient location or other intrinsic virtues), property price differences can remain even in the longest time horizon. 
There are two cases of interest. In the first case, the local price indices can vary independently because properties are not homogeneous in the relevant time horizon.

In this case, a change in the state income tax rates is capitalized in property prices (and therefore reflected in the associated rents and in the implicit rents of homeowners). The gross wages do not change at all to keep the real net wages equal to the opportunity cost in other states. Since gross wages are unchanged, it is not necessary to consider the production side of the economy.

This case is important because it shows that an empirical finding that the distribution of gross money wages is unaffected by the state tax rates $(\beta=0$ in equation 2$)$ would not imply that state taxes can redistribute real incomes within the state. Although a rise in the tax rate for a particular group of workers would reduce the net money wage of that group, the net real wage would be unchanged since the local price index would adjust to stabilize the net real wage. Of course, an estimate of $\beta=0$ would not imply that the tax differences were capitalized in property values and that state taxes cannot redistribute income, only that that may be occurring. Thus, an estimate of $\beta=0$ is ambiguous evidence about the effect of the state tax structure or real net incomes.

In the second case, which appears from the data analyzed below to be the more relevant one in practice, property is sufficiently homogeneous that it is better to represent the local price indices as equal: $\mathrm{P}_{\mathrm{H}}=\mathrm{P}_{\mathrm{L}}=\mathrm{p}$. In this case, a change in state income tax rates requires a change in gross inoney wages if household equilibrium is to be maintained:

$$
\left(1-t_{11}\right) w_{11} / p=(1)
$$




$$
\left(1-t_{L}\right) w_{L} / p=\omega_{L} .
$$

The level of prices in the state may change but will not if gross money wages adjust enough to keep net money wages constant; this corresponds to an estimated elasticity of $\beta=-1$ in equation 2.

To illustrate how equilibrium can require gross money wages to adjust to keep net money wages unchanged, we expand the model to include a simplified specification of the firms' demand for labor of the two types. This model of labor demand is simplified by assuming that firms are homogeneous, that they sell their product in a national market, and that their technology is Cobb Douglas. Firms can obtain capital at a user cost of $r$ per unit of capital. For any arbitrary level of output $\left(Q^{*}\right),{ }^{7}$ the firm chooses the input levels of capital $(\mathrm{K})$, of high skilled labor $(\mathrm{H})$, and of low skilled labor $(\mathrm{L})$ to minimize cost subject to the requirement that output is equal to the desired level:

$$
\mathbf{L}=\mathbf{r K}+w_{H} H+w_{L} L-\lambda\left[K^{\alpha} L^{\beta} H^{1-\alpha-\beta}-Q^{*}\right]
$$

This implies the firm's four first order conditions that determine $K, H, L$ and $\lambda$ :

$$
\text { (8) } \quad r=\lambda \alpha Q * K^{-1}
$$

'With constant returns to scale, no restricted input, and an ability to sell output at a constant price in the national market, the quantity produced by any firm is indeterminate 
(9) $\quad w_{L}=\lambda \beta Q^{*} L^{-1}$

(10) $\quad \mathrm{w}_{\mathrm{H}}=\lambda(1-\alpha-\beta) \mathrm{Q} * \mathrm{H}^{-1}$

(11) $K^{\alpha} L^{\beta} H^{1-\alpha-a}=Q *$

Combining these first order conditions for the firm to minimize cost with the two household equilibrium conditions required for utility maximization (equations 5 and 6) and simplifying yields an equation for the wage of the high skilled individuals as a function of the tax rates:

(12) $[(1-\alpha) / \beta] \ln w_{H}=\ln \left(1-t_{L}\right)-\ln \left(1-t_{H}\right)+$ constant.

Thus

(13) $d \ln w_{H}=[\beta /(1-\alpha)]\left\{d t_{H} /\left(1-t_{H}\right)-d t_{L} /\left(1-t_{L}\right)\right\}$.

Since $1-\alpha$ is the production function coefficient corresponding to the share of labor and $\beta$ is the corresponding share of low skilled labor, it is clear that $[\dot{\beta} /(1-\alpha)]<1$. Thus an increase in tax progressivity, as measured by the difference between the proportional increases in the high and low tax rates, causes a less than proportional increase in the gross wage of the higlt skilled individual. Similarly. it can be shown that 


$$
\left.d \ln w_{L}=-\{1-\alpha-\beta) /(1-\alpha)\right]\left\{d t_{H} /\left(1-t_{H}\right)-d t_{L} /\left(1-t_{L}\right)\right\}
$$

The economic reasons for this change can be understood easily by considering the response to an increase in the tax rate on high skilled individuals. Their real wage must rise to compensate for the higher tax rate. A portion of that rise must come in the form of a higher money wage since in this case property is homogeneous. Since that higher money wage for high skilled employees raises the cost of production to the firm, the firm can only continue to produce in the state if the wage of low skilled employees falls. Of course, low skilled employees will only remain in the state if the state price level falls enough (through the decline in the value of land) to offset the lower money wage. This fall in the state price level also explains why the wage of the high skilled employees does not have to rise by the same proportion as the decline in the net of tax share. In equilibrium, the combination of higher money wage for the high skilled employees, lower money wage for the low skilled employees, and lower land prices keeps the real net incomes of both types of employees unchanged and the firms' real cost of production unchanged.

The effect of a revenue neutral change in tax progressivity can be calculated by constraining the overall tax revenue, $T=t_{H} w_{H} H+t_{L} w_{L} L$, to remain unchanged. The first order change in tax revenue implies:

$$
d T=w_{H} H d t_{11}+w_{L} L d t_{L}=0
$$

or, using the first order conditions of equations 9 and 10 , 


$$
(1-\alpha-\beta) \lambda Q * d t_{H}+\beta \lambda Q * d t_{L}=0 \text {. }
$$

Thus the revenue neutral change in progressivity implies

$$
d t_{L}=-[(1-\alpha-\beta) / \beta] d t_{H}
$$

an increase in the tax on high skilled individuals must be balanced by a decrease in the tax on low skilled individuals in a ratio that reflects their shares in total labor income.

Combining this revenue neutral requirement with equation 13 implies that a revenue neutral shift from a proportional tax $\left(t_{H}=t_{L}\right)$ to a progressive tax $\left(t_{H}>t_{\mathcal{L}}\right)$ causes the wage of the high skilled taxpayer to increase by the same proportion that the net-of-tax share $\left(1-t_{H}\right)$ decreases:

$$
d \ln w_{H}=-\left[d\left(1-t_{H}\right)\right] /\left(1-t_{H}\right)
$$

Thus this increase in progressivity causes the gross wage to rise by enough so that the net wage $\left[w_{14}\left(1-t_{11}\right)\right]$ remains unchanged. In terms of equation 2 , the estimated coefficient of the net after tax variable would be minus one in this model. It follows also that a revenue neurral increase in progressivity causes the gross pretax wage of low-skilled workers to fall by the proportional decrease in the net of tax share, again leaving the net real wage unchanged: 
$d \ln w_{L}=-\left[d\left(1-t_{L}\right)\right] /\left(1-t_{L}\right)$.

Returning to equations 4 and 5 , it is clear that in this case an increase in progressivity leaves the households in equilibrium because the resulting change in gross money wages leaves net money wages unchanged, requiring no change in property prices. Firms also remain in equilibrium because, although they pay a higher gross wage to high skilled employees, the decline in the wage paid to low skilled employees is enough to keep total cost of production unchanged. The shift in relative gross wages causes furms in the state to reduce the number of high skilled employees and increase the number of low skilled employees.

The purpose of the analysis in this section is not to predict how wages will respond to changes in progressivity but to show that even when tax progressivity cannot change the distribution of real incomes it can change the distribution of money incomes. The gap between money wage changes and real wage changes could be offset by differential changes in property prices. Thus an empirical finding that gross money wages are unaffected by changes in state tax progressivity (corresponding to $\beta=0$ in equation 2) would not be conclusive evidence against the proposition that state tax policies cannot change the distribution of real incomes. At the opposite extreme, a finding that a change in progressivity leaves net money wages unchanged $(\beta-1$ in equation 2$)$ is of course evidence in favor of the proposition that state tax policies cannot change the distribution of real incomes. We turn now to the empirical estimates of equation 2, aware of this ambiguity and of the reasons discussed in section 1 why the structure of wages in the state might not be 
independent of state income taxes even in the very long run. Despite these possibilities, the evidence presented below supports the conclusion that gross money wages adjust to state tax policies in a way that leaves net money wages unaffected by state tax rules and that this adjustment occurs fast enough so that the observed differences in state tax rates does not affect current net money wages.

\section{The Data and the Definition of Variables}

Our analysis uses the Current Population Survey (CPS) data for March 1983 and March 1989 to relate the individual's pretax average hourly wage rate $e^{8}$ to the net average tax rate and to a variety of demographic characteristics as suggested by equation 2 above. State specific constant terms are used instead of trying to identify and measure all of the amenities and other state characteristics that would influence local wages. The sample is limited to individuals who worked between 35 and 70 hours per week. Separate equations are estimated for men and women.

To estimate the tax parameters, we use the federal and state tax rules included in the NBER's TAXSIM model (and other procedures described below) to impute net average tax

\footnotetext{
${ }^{8}$ The hourly wage variable is constructed by dividing the reported usual weekly wage by the reported usual weekly hours. Since there are problems with the "usual weekly wage" available in the March 1983 CPS, we match each person in the March data with his or her wage when he or she is in the outgoing rotation group in March through June.
} 
rates $\left(\mathrm{NATR}_{\text {is }}\right.$ ) to each individual. ${ }^{9}$ In 1983 , the data permit us to define the net average tax rate of individual $i$ as

$$
\text { NATR }_{i}=\text { FATR }_{i}+\left[1-\text { itemprobab }_{i} \times \text { FMTR }_{i}\right]\left[\text { SATR }_{i}+\text { PATR }_{i}+\text { SLATR }_{l}\right]
$$

where: FATR $_{i}$ is the share of total income of individual i paid in federal income tax; itemprob $b_{i}$ is the probability that individual $i$ itemizes deductions in calculating taxable income for the federal income tax ${ }^{10} ;$ FMTR $_{i}$ is the marginal federal income tax rate of individual $i$; SATR $_{i}$ is the share of total income of individual $i$ paid in state income tax; SLATR $_{i}$ is the share of the total income of individual $i$ paid in state sales tax; and PATR is the share of total income of individual $i$ paid in property taxes. The method of calculating each of these variables will now be described.

The federal income tax share $\left(\right.$ FATR $_{\mathrm{i}}$ ) is defined as the ratio of the federal income tax liability to total money income. It is calculated by applying the federal income tax rules to the income of the taxpayer unit (i.e., the individual or married couple) of which individual $i$ is a member, using the NBER's TAXSIM Model based on the income and family structure reported in the CPS data. The federal marginal tax rate $($ FMTR $)$ facing individual $i$ is calculated in the same way.

${ }^{9}$ The year 1989 is the most recent year for which the necessary data on state income and property taxes are available. We study the data for 1983 because that is the most recent year for which Feenberg and Rosen (1986) have estimated the average sales tax paid by different income groups in different states.

${ }^{10}$ Itemizing deductions reduces the net cost of taxes paid to state and local governments by a fraction equal to the federal marginal tax rate. The calculation of isemprob $b_{i}$ is described below. 
The probability that the individual itemizes federal tax deductions (itemprob;) is estimated on the basis of the 1983 and 1989 Internal Revenue Service Public Use Samples of individual federal income tax returns. These IRS data indicate whether the taxpayer itemizes, the state of residence, and the taxpayer's income and filing status (single, married, etc.). We rank the states according to the fraction of taxpayers in each state who itemize and then divide the states into five groups. Within each state group, taxpayers are classified into one of 10 income level groups. We use the IRS data to estimate an equation that relates itemization to filing status and to the $\mathbf{5 0}$ state-income categories and use this equation to calculate the probability that each individual in our CPS sample is an itemizer.

The state income tax share $\left(\mathrm{SATR}_{\mathfrak{i}}\right)$ is defined as the ratio of the state income tax liability to the total money income of the taxpayer unit. The NBER's TAXSIM model contains summaries of the tax rules for defining taxable income in each state and of the state's structure of tax rates.

The property tax share (PATR $)$ is the ratio of the property tax that individual $i$ would pay as a homeowner to total money income. We use the tax that would be paid by homeowners to estimate the residential property tax liability of all households on the assumption that renters bear a comparable tax burden through their rent. Our estimate of the property tax individual i would pay is based on the income of that individual, the national relationship between income and housing values, and the residential property taxes paid in the individual's state of residence.

The starting point for our calculation of the property tax attributable to individual $i$ is the assumption that a homeowner's house value in state s can be approximated by 
$v_{i s}=a_{s} h\left(y_{i}\right)$ where $v_{i s}$ is the value of the property of individual $i$ in state $s, a_{3}$ is an unobservable factor that accounts for differences among states in house prices, and $h\left(y_{i}\right)$ is the national relation between housing value and income class. ${ }^{11}$ It is not necessary to calculate $a_{3}$ explicitly since we are interested in property tax payments and not in house values per se. We assume that the property tax paid by a homeowner in state $s$ is proportional to his or her residential property value with an unobservable state-specific average tax rate $\left(t_{3}\right)$. This implies that the property tax for individual $i$ is $t_{3} v_{i s}=t_{4} \quad a_{3} h\left(y_{i}\right)$. Estimating the individual's property tax therefore does not require separate estimates of the average state property tax rate $\left(t_{3}\right)$ and the relative property value factor $\left(a_{3}\right)$ but only of their product $\left(\mathrm{s}_{3}\right)$.

Since the $t_{4}$ and $a_{3}$ variables are assumed to be constant within each state, their product $\left(\mathrm{L}_{\mathrm{a}}\right)$ can be estimated on the basis of the total residential property tax paid in state s. The total property tax paid in state $i$ is the sum of $t_{s} a_{3} h\left(y_{i}\right)$ over all taxpayer units in state $s$. Denoting the known distribution of income in state $s$ by $f_{s i}\left(y_{i}\right)$, it is possible to calculate $\Sigma_{i} f_{s i}\left(y_{i}\right) h\left(y_{i}\right)$; the value of $t_{3} a_{3}$ can then be estimated as the ratio of total residential property taxes collected in state $s$ to $\Sigma_{i} f_{s i}\left(y_{i}\right) h\left(y_{i}\right) \cdot{ }^{12}$ With that value for $t_{s} a_{3}$,

\footnotetext{
"We estimate this relation for 1983 on the basis of the 1983 Annual Housing Survey (U.S. Department of Housing and Urban Development, 1984) and for 1989 on the 1989 Annual Housing Survey (U.S. Department of Housing and Urban Development, 1991).

${ }^{12}$ To implement this calculation for 1983, we use the data on property tax revenue by state in 1983 published in Advisory Committee on Intergovernmental Relations (1985) and data on the percent of gross assessed value of taxable real property that is residential from the Census of Governments for 1981 (U.S. Department of Commerce, 1984). A sinilar procedure is used for 1989 .
} 
the property tax for each individual in the CPS sample is calculated as $t_{s} a_{s} h\left(y_{i}\right)$. The property tax share in income, PATR individual.

The estimated share of total money income paid in sales tax is based on the study of Feenberg and Rosen (1986). They used the IRS state sales tax allowance figures for 1983 to estimate a regression of sales tax payments on income and family size. We use the Feenberg and Rosen equation to impute a sales tax liability to each taxpayer and therefore to calculate the corresponding income share, SLATR .

The demographic variables included in our specification of equation 2 are marital status, number of children under age 6 , number of children under age 18, race, years of education (as a series of dummy variables), years of experience and its square, and whether or not the individual lives in an SMSA.

The analysis for 1989 is quite similar. ${ }^{13}$ Unfortunately, there are no data for 1989 that are comparable to the Feenberg-Rosen estimated sales taxes by income class in 1983.

\section{The Endogeneity of the Tax Rate}

Because each individual's tax rate is dependent on the wage that that individual receives and on how much the individual works at that wage, the stochastic error in the wage equation will be correlated with the net-of-tax variable. Ordinary least squares estimates will therefore be biased. More specifically, since a higher wage will generally be negatively

\footnotetext{
${ }^{13}$ The wage regression for 1989 includes a dummy variable for union membership that was not available for 1983 .
} 
correlated with the net-of-tax variable, ${ }^{14}$ the estimated coefficient of the net of tax variable in the ordinary least squares estimate of the wage equation will be biased down, i.e., toward a more negative coefficient.

An instrumental variable estimator can eliminate this bias in the large samples of data on which our estimates are based. An appropriate instrumental variable should be uncorrelated with the disturbance in the wage equation but correlated with the net-of-tax variable that would apply to the expected value of the individual's wage. To construct such an instrumental variable, we begin by estimating a regression equation relating each individual's wage and salary income to several demographic variables: education, year of experience, the square of the years of experience, marital status, children, race, residence in an SMSA, union membership (when available) and a set of state dummy variables. We use this equation to form a predicted wage and salary income for each individual. We then combine these individual predicted wage and salary incomes for husband and wives in married taxpayer units and add actual nonlabor income for the taxpayer unit. We use these predicted incomes to recalculate each of the average tax rate variables (FATR, SATR, PATR and SLATR), the probability of being an itemizer (itemprob) and the marginal federal tax rate (FMTR). Finally, we combine these variables according to the specification of equation 20 to calculate a predicted Net Average Tax Rate (NATR*) and then use $\ln \left(1-\mathrm{NATR}^{*}\right)$ as the instrumental variable for In (1-NATR).

\footnotetext{
${ }^{14}$ We say "generally" because the net-of-tax variable refers to the taxpaycr unit as a whole while the wage disturbance refers to a single individual within that unit.
} 


\section{The Empirical Results}

Table I presents the estimated coefficients of the net of tax variable [In (1-NATR)] of equation 2; since the coefficients of the demographic variables and the individual constant terms are not of direct interest, they are not reported but are available from the authors. The use of separate constant terms for each state is equivalent to measuring each variable relative to the mean of that variable for the individual's state. This implies that the coefficient of each variable measures the effect of deviations of the variable from the state mean. In particular, the coefficient of the net-of-tax variable measures the effect of the progressivity of the tax structure rather than the level of taxes in the state.

The first row of Tabje 1 shows the result for the sample of men in 1983. The instrumental variable estimate of the elasticity of the gross wage with respect to the net of tax share ( $\beta$ of equation 2 ) is -0.62 with a standard error of 0.36 . This estimate is not significantly different from the value of minus one that would imply that tax progressivity causes no change in net wages.

The estimated coefficient is not just an indication of the Jong-run tendency of gross wages to adjust to the progressivity of the state tax structure but is also a measure of the extent to which gross wages had adjusted by 1983 to the past changes in tax rates. These changes in 1-NATR reflect not only the changes in state and local tax rates but also the sharp changes in fecleral marginal and average tax rates that were enacted in 1981. The point estimate implies that 62 percent of the existing differences in tax progressivity had already been shifted by 1983 through adjustments in gross wages. 
This evidence on the adjustment of gross wages to tax rates is compatible with three other types of evidence on the responsiveness of the labor market. First, there is substantial evidence of rapid change in the national distribution of wages in the $1980 \mathrm{~s}$ in response to a variety of factors, including changes in technology, trade, and the educational mix of the labor force (Card, 1992; Freeman, 1994). This experience leaves little doubt about the general ability of wages to adjust quickly. Second, the evidence on the response of individual labor supply and, more generally of taxable incomes, to changes in tax rates shows quite rapid responses (Eissa, 1993; Feldstein, 1994). Finally, the research of Blanchard and Katz (1992) shows that migration away from high unemployment areas is rapid enough to return the unemployment rate to normal six years after an adverse demand shock.

The final column presents the corresponding ordinary least squares estimate. The value of -3.09 shows the anticipated negative bias that occurs because of the correlation between the error term in this wage equation and the net-of-tax-share variable. The ordinary least squares estimates are presented in Table 1 only as an indication of the importance of using instrumental variable estimation in the current context.

The estimated net-of-tax-share elasticity for women in 1983, shown in row 2 , is -0.92 with a standard error of 0.33 . This point estimate implies an even larger degree of effective shifting of the tax than the coefficient for men, although the difference between the coefficients is not statistically significant. 
Table 1

The Elasticity of the Gross Hourly Wage to the Net-of-Tax Share

\begin{tabular}{|c|c|c|c|c|c|c|}
\hline Row & Year & Men/Women & $\begin{array}{l}\text { Sample } \\
\text { Size }\end{array}$ & Sales Tax & $\begin{array}{l}\text { Instrumental } \\
\text { Variable }\end{array}$ & $\begin{array}{l}\text { Ordinary } \\
\text { Least Squares }\end{array}$ \\
\hline 1 & 1983 & Men & 14070 & Included & $\begin{array}{l}-0.62 \\
(0.36)\end{array}$ & $\begin{array}{l}-3.09 \\
(0.05)\end{array}$ \\
\hline-2 & 1983 & Women & 9494 & Included & $\begin{array}{l}-0.92 \\
(0.33)\end{array}$ & $\begin{array}{l}-2.64 \\
(0.06)\end{array}$ \\
\hline 3 & 1983 & Men & 14070 & Excluded & $\begin{array}{l}-0.74 \\
(0.32)\end{array}$ & $\begin{array}{l}-2.97 \\
(0.05)\end{array}$ \\
\hline 4 & 1983 & Women & 9494 & Excluded & $\begin{array}{l}-0.86 \\
(0.31)\end{array}$ & $\begin{array}{l}-2.56 \\
(0.06)\end{array}$ \\
\hline 5 & 1989 & Men & 5049 & Excluded & $\begin{array}{l}-2.08 \\
(0.34)\end{array}$ & $\begin{array}{l}-3.50 \\
(0.09)\end{array}$ \\
\hline 6 & 1989 & Women & 3854 & Excluded & $\begin{array}{l}-1.12 \\
(0.26)\end{array}$ & $\begin{array}{l}-2.44 \\
(0.09)\end{array}$ \\
\hline
\end{tabular}

Regression coefficients are from a regression of $\ln$ (wage) on In (1-NATR) with controls for education, experience, marital status, number of children, and race. A separate constant term for each state controls for the state specific effects. 
Because data on the sales tax component of the NATR variable are not available for 1989, we present estimates to show the effect of omitting the sales tax component from the NATR for 1983 . The estimate for men (row 3 ) of -0.74 differs only slightly from the estimate of -0.62 (row 1) that is based on the full value of the NATR variable. Similarly, the estimate for women (row 4 ) of -0.86 is very close to the full NATR estimate of -0.92 (row 2). Since the difference is -0.12 in the first case and +0.06 in the second case, there is no evidence of a systematic direction of bias from omitting the sales tax information.

The estimated coefficients for 1989 are absolutely larger than the corresponding coefficients for 1983. For men the estimated coefficient is a surprisingly large -2.08 (with a standard error of 0.34 ) while for women it is -1.12 (with a standard error of 0.26 .) These estimates also suggest that the response to changes in progressivity is so rapid that gross wages have fully adjusted to all pre-1989 tax changes.

The data also permit an explicit analysis of the speed of adjustment. We augment the basic specification of equation 2 for 1989 by adding the net-of-tax share variable for 1983 to the equation as an additional regressor. More specifically, since this is not panel data, we have calculated what 1-NATR would have been for individual i (in the 1989 sample) under 
the tax rules that prevailed in $1983 .^{15}$ We also calculate the corresponding instrumental variable and use the two instrumental variables in the estimation. The estimated coefficients for the two net-after-tax share variables are: ${ }^{16}$

$\begin{array}{lcc} & \ln \left(1-\mathrm{NATR}_{(1989)}\right) & \ln \left(1-\mathrm{NATR}_{(1983)}\right) \\ \text { Men } & -1.64 & -0.43 \\ & (0.96) & (0.60) \\ \text { Women } & -1.73 & 0.43 \\ & (0.38) & (0.38)\end{array}$

The striking finding is that the lagged tax variable is not significantly different from zero for either men or women. This implies that the gross wage in 1989 had adjusted to the 1989 tax structure and was no longer influenced by the tax structure that had prevailed as recently as 1983 . The combination of this result and the evidence of Table 1 implies that the

\footnotetext{
${ }^{15}$ This calculation for 1983 excludes the sales taxes because they are not available for 1989 . Although the tax rates and progressivity measures are of course correlated across states between 1983 and 1989 , there is enough variation between even these two dates so that the evidence of complete adjustment implies a significant adjustment to recent changes. More specifically, using the difference between the net of tax shares at $\$ 100,000$ and at $\$ 25,000$ as the measure of progressivity, the correlation between progressivity in 1983 and progressivity in 1989 is 0.89 . Alternatively, if progressivity is defined as the difference between the net of tax shares at $\$ 100,000$ and at $\$ 10,000$, the correlation between progressivity in 1983 and in 1989 is 0.86 . Either way, less than 80 percent of the interstate variation in progressivity in 1989 can be explained by the corresponding variation in 1983 .

${ }^{16}$ These coefficients are from a regression of $\ln$ (wage) on $\ln \left(1-\mathrm{NATR}_{\mathrm{kg}}\right)$ and $\ln (1-$ $\mathrm{NATR}_{\mathrm{B3}}$ ) as well as variables for education, experience, marital status, number of children, and race. A separate constant term for each state controls for the state specific elfects.
} 
adjustment of the gross wage is quite rapid as well as virtually complete, causing the net wage to remain essentially unaffected by changes in state tax progressivity.

\section{Conclusion}

The evidence presented in this paper supports the basic theoretical presumption that state and local governments cannot redistribute income. Since individuals can avoid unfavorable taxes by migrating to jurisdictions that offer more favorable tax conditions, a relatively unfavorable tax will cause affected individuals to migrate out until the gross wage is raised to a level at which the resulting net wage is equal to that available elsewhere. Similarly favorable tax rates attract in-migrants until their gross wage is depressed to the level at which there is no net advantage to locating in the state.

The current empirical findings go beyond confirming this long-run tendency and show that gross wages adjust rapidly to the changing tax environment. Thus, states cannot redistribute income for a period of even a few years.

The adjustment of gross wages to tax rates implies that a more progressive tax system raises the cost to firms of hiring more highly skilled employees and reduces the cost of lower skilled labor. A more progressive tax thus induces firms to hire fewer high skilled employees and to hire more low skilled employees.

Since state taxes cannot alter net wages, there can be no trade-off at the state level between distribution goals and economic efficiency. Shifts in state tax progressivity, by altering the structure of employment in the state and distorting the mix of labor inputs used by firms in the state, create deadweight efficiency losses without achieving any net 
redistribution of income. This same conclusion applies of course to local governments and to any other political jurisdictions, including nations, when there is sufficient scope for migration. 


\section{References}

Advisory Commission on Intergovernmental Relations, Significant Features of Fiscal

Federalism, Washington, D.C.: Government Printing Office, 1985.

Advisory Commission on Intergovernmental Relations, Significant Features of Fiscal

Federalism, Washington, D.C.: Government Printing Office, 1991.

Atkinson, Anthony and Joseph E. Stiglitz, Lectures on Public Economics, New York: McGraw-Hill, 1980.

Blanchard, Olivier and Lawrence Katz, "Regional Evolutions," Brookings Papers on Economic Activity, 1992:1, 1-75.

Card, David, "The Effect of Unions on the Distribution of Wages: Redistribution or Relabelling?" NBER Working Paper No. 4195, October 1992.

Eissa, Nada, "Taxation and Labor Supply of Married Women: The Tax Reform Act of 1986 As A Natural Experiment," mimeo, Harvard University, 1994.

Feenberg, Daniel R. and Harvey S. Rosen, "State Personal Income and Sales Taxes, $1977-$ 1983, "NBER Reprint No. 886, 1986.

Feldstein, Martin, "The Effects of Marginal Tax Rates on Taxable Income: A Panel Study of the 1986 Tax Reform Act," NBER Working Paper No. 4496, October 1993.

Feldstein, Martin, and Gilbert E. Metcalf, "The Effect of Federal Tax Deductibility on State and Local Taxes and Spending, " Journal of Political Economy, 95 (1987), 710-36.

Feldstein, Martin, and Marian Vaillant. "Does Federal Tax Deductibility Explain State Tax Progressivity?" (1994) forthcoming. 
Freeman, Richard B., and Lawrence Katz, "Rising Wage Inequality: The United States versus Other Advanced Countries, " in Working Under Different Rules, Richard Freeman, ed., New York: The Russell Sage Foundation, 1994, 29-62.

Gordon Roger H., "Taxation of Investment and Savings in a World Economy," American Economic Review, 76 (1986) 1086-1102.

Gyourko, Joseph and Joseph Tracy, "The Importance of Local Fiscal Conditions in Analyzing Local Labor Markets, " Joumal of Political Economy, 97 (1989), 1208-31

Musgrave, Richard A., and Peggy B. Musgrave, Public Finance in Theory and Practice, New York: McGraw-Hill, 1973.

Oates, Wallace, Fiscal Federalism, New York: Harcourt Brace Jovanovich, 1972.

Stiglitz, Joseph E., Economics of the Public Sector, New York: W.W. Norton and Company, 1988.

Tiebout, C., "A Pure Theory of Local Expenditures," Joumal of Political Economy, 64 (1956), 416-24.

U.S. Department of Commerce, Bureau of the Census, Annual Housing Survey 1983, Part C. Financial Characteristics of the Housing Inventory, Washington, D.C.: U.S. Government Printing Office, 1984.

U.S. Department of Commerce, Bureau of the Census, Current Housing Reports H 150/89, American Housing Survey for the United States in 1989, Washington, D.C.: U.S. Government Printing Offīce, 1984. 
U.S. Department of Commerce, Bureau of the Census, 1982 Census of Governments,

Volume 2, Taxable Property Values, Washington, D.C.: U.S. Government Printing Office, 1988.

Wallace, Sally, "The Effects of State Personal Income Tax Differentials on Wages,"

Regional Science and Urban Economics, 23 (1993), 611-628. 


\section{Appendix}

Table Al

1983 Average State Tax Rates at Incomes of $\$ 10,000, \$ 25,000$, and $\$ 100,000$ (Income, Sales, and Property Taxes)

\begin{tabular}{|c|c|c|c|c|c|}
\hline STATE & ATR (10K) & ATR (25K) & ATR (100K) & $\begin{array}{l}\operatorname{ATR}(100 \mathrm{~K}) \\
-\operatorname{ATR}(10 \mathrm{~K})\end{array}$ & $\begin{array}{l}\operatorname{ATR}(100 \mathrm{~K}) \\
-\operatorname{ATR}(25 \mathrm{~K})\end{array}$ \\
\hline AL & .037 & .034 & .034 & -.003 & 0 \\
\hline AK & .061 & .032 & .021 & -.040 & -.011 \\
\hline $\mathbf{A Z}$ & .057 & .054 & .054 & -.003 & .001 \\
\hline$A R$ & .042 & .041 & .057 & .015 & .016 \\
\hline CA & .053 & .043 & .071 & .018 & .029 \\
\hline $\mathrm{CO}$ & .058 & .047 & .054 & -.004 & .006 \\
\hline $\mathrm{Cr}$ & .082 & .048 & .032 & -.050 & -.015 \\
\hline DB & .042 & .050 & .081 & .040 & .031 \\
\hline DC & .081 & .079 & .098 & .016 & .018 \\
\hline FI & .050 & $\begin{array}{r}.029 \\
050\end{array}$ & $\begin{array}{r}.020 \\
058\end{array}$ & -.030 & -.010 \\
\hline GA & .051 & .050 & .058 & .007 & .008 \\
\hline HI & .072 & .069 & .080 & .009 & .011 \\
\hline ID & .045 & .059 & .068 & .022 & .009 \\
\hline II & .077 & .059 & .049 & -.028 & -.009 \\
\hline IN & .071 & .056 & .048 & -.023 & -.008 \\
\hline IA & .044 & .056 & .064 & .020 & .007 \\
\hline KS & .050 & .040 & .053 & .004 & .014 \\
\hline $\mathbf{K Y}$ & .056 & .049 & .045 & -.011 & -.004 \\
\hline LA & .025 & .023 & .027 & .002 & .004 \\
\hline $\mathrm{MB}$ & .069 & .052 & .080 & .011 & .028 \\
\hline MD & .065 & .063 & .058 & -.007 & -.005 \\
\hline MA & .093 & .078 & .075 & -.018 & -.003 \\
\hline MI & .101 & .091 & .085 & -.016 & -.006 \\
\hline MN & .066 & .082 & .096 & .031 & .014 \\
\hline MS & .045 & .036 & .045 & 0 & .009 \\
\hline MO & .045 & .042 & .043 & -.001 & .001 \\
\hline MT & .064 & .061 & .083 & .019 & .023 \\
\hline NB & .048 & .046 & .061 & .013 & .015 \\
\hline MV & .034 & .021 & .014 & -.020 & -.007 \\
\hline NH & .068 & .035 & .023 & -.045 & -.012 \\
\hline NJ & .081 & .056 & .053 & -.028 & -.003 \\
\hline NM & .035 & .023 & .042 & .008 & .019 \\
\hline NY & .070 & .065 & .091 & .021 & .027 \\
\hline NC & .052 & .051 & .062 & .009 & .011 \\
\hline ND & .028 & .027 & .034 & .005 & .007 \\
\hline $\mathrm{OH}$ & .055 & .048 & .064 & .009 & .017 \\
\hline OK & .031 & .027 & .049 & .018 & .022 \\
\hline OR & .050 & .069 & .086 & .036 & .017 \\
\hline PA & .069 & .051 & .042 & -.027 & -.009 \\
\hline $\mathbf{R I}$ & .083 & .069 & .086 & .004 & .018 \\
\hline SC & .057 & .052 & .063 & .006 & .012 \\
\hline SD & .041 & .025 & .016 & -.026 & -.009 \\
\hline TN & .040 & .025 & .016 & -.024 & -.009 \\
\hline$T X$ & .032 & .019 & .013 & $=.019$ & -.006 \\
\hline UT & .080 & .069 & .062 & -.019 & -.008 \\
\hline VT & .031 & .045 & .079 & $.04 B$ & .034 \\
\hline VA & .061 & .057 & .061 & 0 & .004 \\
\hline WA & .063 & .038 & .025 & -.038 & -.013 \\
\hline WV & .051 & .040 & .062 & .011 & .022 \\
\hline WI & .068 & .073 & .091 & .023 & .017 \\
\hline WY & $.08 B$ & .048 & .031 & -.056 & -.017 \\
\hline
\end{tabular}

Based on the state average of property taxes levied at the local level. Does not include local income and sales taxes. 
Table A2

1989 Average State Tax Rates at Incomes of $\$ 10,000, \$ 25,000,0$ and $\$ 100,000$ (Income and property Taxes)

\begin{tabular}{|c|c|c|c|c|c|}
\hline STATE & $\operatorname{ATR}(10 K)$ & ATR (25K) & $\operatorname{ATR}(100 K)$ & $\begin{array}{l}\text { ATR (10OK) } \\
-A T R(10 K)\end{array}$ & $\begin{array}{l}\text { ATR }(100 K) \\
-\operatorname{ATR}(25 \mathrm{~K})\end{array}$ \\
\hline AL & .027 & .026 & .030 & .003 & .004 \\
\hline AK & .067 & .037 & .025 & -.042 & -.012 \\
\hline$A Z$ & .050 & .052 & .054 & .004 & .002 \\
\hline$A R$ & .036 & .040 & .055 & .019 & .015 \\
\hline $\mathrm{CA}$ & .034 & .027 & .063 & .029 & .035 \\
\hline $\mathrm{CO}$ & .063 & .054 & .052 & -.010 & -.002 \\
\hline CT & .059 & .033 & .026 & -.033 & -.007 \\
\hline$D E$ & .037 & .044 & .060 & .024 & .017 \\
\hline$D C$ & .077 & .075 & .089 & .011 & .014 \\
\hline FL & .042 & .023 & .016 & -.026 & -.007 \\
\hline GA & .044 & .050 & .056 & .012 & .006 \\
\hline $\mathrm{HI}$ & .025 & .043 & .068 & .044 & .025 \\
\hline ID & .039 & .059 & .068 & .029 & .009 \\
\hline IL & .062 & .048 & .043 & -.019 & -.005 \\
\hline IN & .059 & .049 & .045 & -.014 & -.004 \\
\hline IA & .057 & .052 & .060 & .003 & .008 \\
\hline $\mathrm{KS}$ & .035 & .040 & .035 & 0 & -.005 \\
\hline KY & .051 & .043 & .041 & -.010 & -.002 \\
\hline IA & .025 & .027 & .032 & .000 & .005 \\
\hline ME & .054 & .053 & .074 & .020 & .021 \\
\hline $\mathrm{MD}$ & .060 & .055 & .053 & -.008 & -.002 \\
\hline MA & .049 & .069 & .070 & .020 & 0 \\
\hline MI & .080 & .066 & .064 & -.016 & -.002 \\
\hline $\mathbf{M N}$ & .053 & .062 & .073 & .020 & .011 \\
\hline MS & .024 & .030 & .042 & .018 & .011 \\
\hline MO & .024 & .035 & .038 & .014 & .004 \\
\hline MT & .065 & .070 & .091 & .026 & .021 \\
\hline NB & .046 & .042 & .052 & .006 & .010 \\
\hline NV & .021 & .012 & .008 & -.013 & -.004 \\
\hline $\mathrm{NH}$ & .065 & .036 & .025 & -.040 & -.011 \\
\hline NJ & .076 & .053 & .052 & -.023 & -.001 \\
\hline NM & .023 & .024 & .052 & .029 & $.02 \theta$ \\
\hline NY & .049 & .056 & .077 & $.02 \theta$ & .020 \\
\hline $\mathrm{NC}$ & .058 & .061 & .063 & .005 & .001 \\
\hline ND & .020 & .024 & .033 & .013 & .009 \\
\hline $\mathrm{OH}$ & .043 & .043 & .058 & .014 & .015 \\
\hline OK & .028 & .036 & .050 & .022 & .014 \\
\hline OR & .055 & .070 & .079 & .024 & .009 \\
\hline PA & .055 & .040 & .034 & -.021 & -.006 \\
\hline RI & .066 & .055 & .065 & -.001 & .009 \\
\hline $\mathrm{SC}$ & .033 & .051 & .061 & .028 & .010 \\
\hline$S D$ & .025 & .014 & .009 & -.015 & -.004 \\
\hline TN & .020 & .012 & .009 & -.011 & -.003 \\
\hline $\mathrm{TX}$ & .033 & .019 & .013 & -.021 & -.006 \\
\hline UT & .047 & .061 & .062 & .014 & .001 \\
\hline VT & .052 & .051 & .065 & .013 & .015 \\
\hline VA & .042 & .053 & .057 & .015 & .004 \\
\hline WA & .038 & .021 & .015 & -.024 & -.007 \\
\hline WV & .041 & .043 & .061 & .020 & .018 \\
\hline WI & .069 & .076 & .077 & .008 & .001 \\
\hline WY & .059 & .033 & .022 & -.036 & -.010 \\
\hline
\end{tabular}

Based on the state average of property taxes levied at the local level. Does not include local income taxes. 